\title{
Katherine Mansfield’s Art of Changing Masks in "Je ne parle pas français"
}

\author{
SHIEH Wen-Shan \\ Shih Chien University, Kaohsiung Campus, Kaohsiung City, Taiwan
}

\begin{abstract}
In a letter to Vita Sackville-West dated 8 August 1931, eight years after Katherine Mansfield’s death, Virginia Woolf confides that she "gave up” reading her literary rival’s stories "because of their cheap sharp sentimentality". Woolf's observation invites us to question: is Mansfield a mere sentimentalist or is her characterisation technique misunderstood? The first section of this paper demonstrates that attributing Mansfield' works as "sentimental" is erroneous since Mansfield's strategy is to change the masks of her characters within her stories, revealed in her letters and journal entries. Following the first section of this paper, I aim to explore how Mansfield extends this strategy of changing masks in daily life to her fictional characters in "Je ne parle pas français” (1918) by equipping them with different types of masks — speech and facial expressions, gender, and animality — to respond to changes in their situations and toward the characters around them. Particularly important to this exploration are Joan Rivière’s insights into gender in her article, “Womanliness as Masquerade”, Michael Goldman’s theory of masks in acting in his The Actor's Freedom: Toward a Theory of Drama and Gilles Deleuze and Félix Guattari's concept of “becoming-animal” in Kafka: Towards a Minor Literature.
\end{abstract}

Keywords: Katherine Mansfield, masks, sentimentality, speech, animal, gender

\section{Introduction}

The first section of this paper traces Katherine Mansfield's art of changing masks with reference to her letters and journal entries. Following the first section of this paper, I will explore how Mansfield's characters switch between three types of masks—-speech and facial expressions, gender, and animality - to respond to changes in their situations. My primary focus will be on one of Mansfield's most experimental stories, "Je ne parle pas français” (1918).

\section{“Sentimentality"}

Katherine Mansfield (1888-1923) established her distinctive voice as a writer of short story with "Prelude" in 1918, published by Virginia and Leonard Woolf's Hogarth Press in London. She died of tuberculosis in Fontainebleau, France, at the age of only $34 .{ }^{1}$ When she heard of Mansfield's death, Virginia Woolf felt that the only literary rival she valued was gone, famously confessing in her diary: "I was jealous of her writing-the only writing I have ever been jealous of” (Woolf, 1978, p. 227). Compared to Virginia Woolf, however, less critical attention has been devoted to Mansfield. As Clare Hanson points out in her contribution to The Gender

SHIEH Wen-Shan, Assistant Professor, Department of Applied English, Shih Chien University.

${ }^{1}$ For more information about Katherine Mansfield's life and career, see Alpers (1987). 
of Modernism, Mansfield "is most commonly viewed as a marginal modernist writer" because of her disadvantaged status "as a woman writer and as a colonial". Hanson also suggests that there is a connection between her "marginal position" and the widespread "assumption that the short story is a minor art form" (Hanson, 1990, pp. 298-300).

Another significant reason that contributes to Mansfield's status as a minor modernist, I argue, is what T. S. Eliot calls the "poignant” quality of her best-known story, "Bliss” (Eliot, 1934, p. 35), ${ }^{2}$ which distinguishes her from her contemporary modernists such as T. S. Eliot himself, who argues in his "Tradition and Individual Talent" that "poetry is not a turning loose of emotion, but an escape from emotion" (Eliot, 1997, pp. 48-49). Deeply affected by the modernist interdiction against sentiment and emotional appeals, Virginia Woolf's dread of being labeled sentimental and her dismissal of the sentimental fill her diary entries and letters. ${ }^{3}$ Despite having confessed her jealousy towards Mansfield's writing, Virginia Woolf has reservations about the "sentimentality" of Mansfield's "little stories", as shown in her letter to Vita Sackville-West dated 8 August 1931, eight years after Mansfield's death:

Only then she [Katherine Mansfield] came out with a swarm of little stories, and I was jealous, no doubt; because they were so praised; but gave up reading them because of their cheap sharp sentimentality, which was all the worse, I thought, because she had, as you say, the zest and the resonance-I mean she could permeate one with her quality; and if one felt this cheap scent in it, it reeked in one's nostrils. (Woolf, 1979, p. 366)

It is noteworthy that Woolf's repulsion towards the sentimentality of Mansfield's works is expressed in terms of something more like a "scent". The "cheap" quality of "scent" suggests that the themes of Mansfield's stories are shallow and the characters in her stories are apt to be swayed by sentiment, or superficial emotions. This leads us to explore the sentimental in relation to what Andrew Bennett calls Mansfield's "fascination with superficiality, with the way in which social worlds are constructed through surfaces” (Bennett, 2004, p. 28).

Mansfield's interest in the superficial can be best illuminated in a letter dated 23 November 1920, in which she explains to her husband John Middleton Murry what she intends in the story "Poison” (1920):

The story is told by (evidently) a worldly, rather cynical (not wholly cynical) man against himself (but not all together) when he was so absolutely young. [...] Its promiscuous love not understood as such by him, perfectly understood as such by her. But you realise the vie of luxe they are living - the very table, sweets, liqueurs, lilies, pearls. And you realise? She expects a letter from someone calling her away? Fully expects it? Which accounts for her farewell \& her declaration. And when it doesn't her commonness peeps out [...] But he also regrets the self who dead privately would have been young enough to have actually wanted to Marry such a woman. But I meant it to be light—-tossed off—and yet through it—oh, subtly - the lament of youthful belief. [...] A glimpse of staleness. And the story is told by a man who gives himself away \& hides his traces at the same moment. (Mansfield, 1996, p. 119)

The phrases such as "promiscuous love", "commonness peeps out", and "the lament of youthful belief" show that the characters in the story are addicted to indulgence in superficial emotion, thus confirming Woolf's charge of sentimentality of Mansfield's stories. Her use of the word "cynical" to describe the tone of the narrator, however, indicates that the narrator actually does not place too much trust in the sincerity of people's speech, which reminds us of the parodic element of the characters' sentimental speech-patterns. Furthermore, the phrase "a man who gives himself away \& hides his traces at the same moment" suggests that there is an

\footnotetext{
2 “Miss Mansfield's story—it is one of her best known ['Bliss']—is brief, poignant and in the best sense, slight” (Eliot, 1934, p. 35).

${ }^{3}$ For more information about Virginia Woolf's struggle with the modernist censors of sentimentality, see Hankins (1993).
} 
issue of masking in the characters' clichéd confessions: the woman uses her declaration of love and marriage to mask the fact that she is expecting a letter from a secret lover; "a glimpse of staleness" has been masked by the I-narrator's naïve enthusiasm for proposing to the woman. This obvious parody of traditional role-playing does not fall within the category of "the sentimental". All in all, I contend that the attribution of sentimentality has been confounded by this strategy of masking in Mansfield's storytelling.

\section{Katherine Mansfield's Strategy of Changing Masks}

The connection between writing and the mask is evident in Mansfield's most famous remark on changing masks, as she writes to her future husband John Middleton Murry in a letter dated late July 1917. Having told Murry that his article on Leon Bloy makes her feel that he is going to "uncover" himself and "quiver", Mansfield gives him a warning:

Even your style of writing changes then-little short sentences—a hand lifted above the waves— the toss of a curly head above the swirling tumble- Its [sic] a terrible thing to be alone—yes it is—it is—but dont [sic] lower your mask until you have another mask prepared beneath—As terrible as you like—but a mask. (Mansfield, 1984, pp. 317-318)

In her view, the linguistic mask is a strategy to solve the problem of "self-torture" or "self-pity" that informs Murry’s explicit writing style. Her warning reveals that Mansfield is not inclined to write explicitly as Murry does. Furthermore, the phrase "another mask prepared beneath" intimates that the seemingly unmasked expression of a person might serve as another underlying mask revealed after the overlying mask has been removed. In the following sections, I will explore how Mansfield extends this strategy of changing masks in daily life to her fictional characters in short stories by equipping them with a multiplicity of masks—-he, she, or it changes masks to meet every moment of the story.

\section{“Je ne parle pas français” (1918)}

The plot of "Je ne parle pas français" (1918) ${ }^{4}$ is not complicated: the I-narrator, a Parisian man, Raoul Duquette, meets an Englishman, Dick Harmon, in Paris. To Raoul's dismay, Dick soon leaves Paris but then later returns with an Englishwoman who is not his wife, and who is called "Mouse" without being properly named. Dick deserts Mouse without having stayed in the hotel rooms he has asked Raoul to book for them, because he feels their elopement would upset his mother. The narrator promises to return to the hotel to lend the abandoned Englishwoman a helping hand, but does not do so.

I have chosen the story as my focus because it encapsulates the full range of masks Mansfield creates for her characters, which I categorise into three types: speech and facial expressions, gender, and animality. As Sydney Janet Kaplan interprets it:

Katherine Mansfield's aesthetics are grounded in a precocious recognition of the self as many selves—male / female being only one of several possible polarities. She had a very early experience of multiplicity (and I want to stress the use of this term rather than fragmentation, which suggests the end of a process, the breaking apart of something that was once whole [...]). (Kaplan, 1991, p. 169)

Indeed, gender is only one of the masks that Mansfield adopts in building her fictional characters. "Je ne parle pas français”, “The Young Girl” (1920), and “A Married Man’s Story” (1921) are examples of her writing

\footnotetext{
${ }^{4}$ In this paper, I use G. Kimber and V. O’Sullivan (Eds.) (2012), The Edinburgh Edition of the Collected Works of Katherine Mansfield (Vol. 2). Unless otherwise indicated, all quotations from Mansfield's short stories are from this edition.
} 
in the form of impersonating a first person male narrator. In addition to gender, her awareness of "multiplicity" is extended to her interest in writing about non-human animals. She names her characters Mouse, Herr Rat, Mr. Reginald Peacock and the Trout boys; she wrote stories entitled "Mr. and Mrs. Dove” (1921), "The Fly" (1922) and "The Canary" (1922). In a letter dated 2 November 1908, she tells Garnet Trowell that her method of holding reader's attention is to "express in the voice and face and atmosphere all that you say" (Mansfield, 1984, p. 84). The letter indicates that a mask of a character is not only created by speech but also by facial expressions. In "Her First Ball” (1921), for instance, the superficial mannerism of the girls attending the ball is demonstrated not only by their speech but also by their strange faces and smiles: "Strange faces smiled at Leila—sweetly, vaguely. Strange voices answered, 'Of course, my dear.' But Leila felt the girls didn’t really see her” (Mansfield, 2012, p. 326).

In the following pages I aim to explore how the characters change these three types of masks-speech and facial expressions, gender, and animality — to respond to changes in their situations and in the characters around them by drawing on Joan Rivière's insights into gender in her article, "Womanliness as Masquerade” (Rivière, 1986, pp. 35-44), Michael Goldman's theory of masks in acting in his The Actor's Freedom: Toward a Theory of Drama (Goldman, 1975), and Gilles Deleuze and Félix Guattari’s concept of “becoming-animal” in Kafka: Toward a Minor Literature (Deleuze \& Guattari, 1986). In my investigation of different types of masks in "Je ne parle pas français”, I will also discuss other stories by Mansfield where appropriate.

\section{“The Fastest-Changing Masks of All”: Speech and Facial Expressions}

In "Je ne parle pas français”, the narrator's descriptions of Mouse which occur in brackets, for instance, remind us of stage directions, such as "(Soft music. Mouse gets up, walks the stage for a moment or so before she returns to her chair [...])” (Mansfield, 2012, p. 130), or "But she shrank away. (False move.)” (Mansfield, 2012, p. 132). Taking the story as a piece of theatre, Michael Goldman's theory of the use of masks in acting helps to illuminate an understanding of Mouse's art of changing masks. In his The Actor's Freedom, Goldman contends that "in the work of any competent playwright or actor, disguise is constantly being assumed and stripped away, constantly growing and transforming” (Goldman, 1975, p. 92). He goes on to emphasise the effectiveness of speech in acting:

Speech in particular, because of its mobility, its density of impressions, should always be thought of as a disguise-a disguise that slips, reveals, changes, strains to be adequate, strains even to be true or transparent to what it describes, breaks away, breaks down, stiffens, must be bolstered up. It is the fastest-changing mask of all. (Goldman, 1975, p. 93)

Keeping Goldman's insights in mind, we can observe how Mouse changes her masks to respond to changes in her situation and in the characters around her:

She wept so strangely. With her eyes shut, with her face quite calm except for the quivering eyelids. The tears pearled down her cheeks and she let them fall.

But feeling my glance upon her she opened her eyes and saw me holding the letter.

"You've read it?"

Her voice was quite calm, but it was not her voice anymore. It was the voice you might imagine coming out of a tiny, cold, sea-shell swept high and dry at last by the salt-tide...

[...]

"I knew all along, of course," said the cold, salty little voice. "From the very moment that we started. I felt it all through me, but I still went on hoping_-” and here she took the handkerchief down and gave me a final glimmer- "as one so stupidly does, you know.” 
“As one does."

Silence.

"But what will you do? You'll go back? You'll see him?”

That made her sit right up and stare across at me.

"What an extraordinary idea!” she said, more coldly than ever. "Of course I shall not dream of seeing him. As for going back-that is quite out of the question. I can't go back.”

"But...” (Mansfield, 2012, p. 132)

As the passage reveals, Mouse's mask of calmness slips when she breaks down. The adverb "strangely", however, seems to hint at a kind of unnaturalness, or artificiality involved in her weeping with a mask, as implied by the phrase "with her face quite calm". Her strange way of weeping makes us wonder if her tears account for another mask she has prepared underneath the one that has slipped. In other words, one of the reasons Mouse cries is her knowledge of crying as a self-conscious performance required by custom on certain social occasions. Soon after crying, however, she mocks her own stupidity and then coldly rejects Raoul's suggestion of following Dick back to England, as if she no longer wants to see him.

At this juncture of my argument, I would like to propose that facial expressions constitute an additional form of mask in Mansfield's stories, aside from Mouse's tears in the passage, a smile worn by Raoul is another mask. "Every word matters", as Mansfield tells Murry in a letter dated 2 February 1920 (Mansfield, 1993, p. 204). Instead of saying simply "he smiled charmingly", the narrator tells us that Dick "flashed the brightest, most charming smile at his little hostess [Mouse]" (Mansfield, 2012, p. 129). Mansfield's use of the word "smile" as a verb and a noun in her descriptions of her characters' smiles foregrounds the sense of smile as a mask. In other words, the possessive words, "his" or "her" before "smile" as a noun indicate that each fictional character has made and wears different kind of smile masks in order to achieve their respective purposes. In "The Doll’s House" (1921), Lil, the daughter of "a spry, hard-working little washerwoman” gives her "silly shamefaced smile" when other "little girls turned around and sneered" (Mansfield, 2012, p. 417). Again, Lil "only gave her silly shamefaced smile" in response to the spiteful question posed by her snobbish classmate Lena, keeping up the masquerade that "she didn’t seem to mind the question at all” (Mansfield, 2012, p. 418). In “A Cup of Tea” (1922), Rosemary Fell encounters a beggar girl, Miss Smith, in Curzon Street in London. To fulfill her own fantasy of being a "fairy godmother" in a fairytale, she brings Miss Smith home with her. Her husband Philip "smiled his charming smile” (Mansfield, 2012, p. 466) at Miss Smith. Eventually, Rosemary ends her "game of sisterly solidarity" (in Andrew Bennett’s phrase) (Bennett, 2004, p. 48), when Philip comments that Miss Smith is “astonishingly pretty” and "absolutely lovely” (Mansfield, 2012, p. 466).

In other stories, even the seemingly unmasked expressions such as rudeness and angriness can also be used as masks. In "Bliss”, Bertha's husband, Harry’s purported rudeness to his wife's friend, Pearl Fulton, is, according to the contemporary British novelist Salley Vickers, "a cover for his own amorous attachment" (Vickers, 2012, p. 13). At the end of "Feuille d'Album” (1917), another short story set in Paris, the expatriate young artist Ian French finally gets a chance to speak to the girl he adores: "Blushing more crimson than ever, but looking at her severely he said, almost angrily: 'Excuse me, Mademoiselle, you dropped this'” (Mansfield, 2012, p. 97). On this occasion, Ian tries to look at her "severely" and speaks "almost angrily" in order to mask his "blushing".

\section{Gender as Masquerade}

Many critics have written about the indeterminate gender and sexuality of Raoul Duquette, the narrator of 
"Je ne parle pas français". His description of himself is, as Pamela Dunbar puts it, "laced with indications of femininity" (Dunbar, 1997, p. 81). He is "light and little" and has "black eyes with long eyelashes, black silky hair cut short, tiny square teeth"; he is "almost like a girl, with smooth shoulders" and "supple and small” hands. Andrew Bennett also points out that Raoul seems to experience "a certain homoerotic fascination towards Harmon [Dick]" (Bennett, 2004, p. 76). When he receives the letter from Dick, he thinks of himself as Madame Butterfly, hearing of the arrival of Lieutenant Pinkerton: ${ }^{5}$

I read it [the letter from Dick] in front of (the unpaid for) wardrobe mirror. It was early morning. I wore a blue kimono embroidered with white birds and my hair was still wet; it lay on my forehead, wet and gleaming.

“Portrait of Madame Butterfly,” said I, “on hearing of the arrival of cecher Pinkerton.” (Mansfield, 2012, p. 122)

This self-portrait of Raoul intimates the extent to which, for Mansfield, womanliness is a mask, an impersonation, or what the psychoanalyst Joan Rivière—a contemporary of Mansfield—calls a "masquerade" (Rivière, 1986, pp. 35-44). In her famous essay, "Womanliness as Masquerade” (1929), Rivière opens with a reference to Sándor Ferenczi's argument that "homosexual men exaggerated their heterosexuality as a 'defence' against their homosexuality”. ${ }^{6}$ She goes on to claim that "women who wish for masculinity may put on a mask of womanliness to avert anxiety and the retribution feared from men” (Rivière, 1986, p. 35). Commenting on Rivière's notion of womanliness as a masquerade, Stephen Heath points out that there is a similar male term for the woman's masquerade— “male display” or, in Lacan's term, "parade” (Heath, 1986, pp. 55-56). Ferenczi's view of heterosexuality as a defense implies that manliness is a kind of masquerade, too. Correspondingly, Dick's Parisian friend, Raoul, masquerades as a chivalrous man who offers to return to the hotel the next day to lend the deserted Englishwoman a hand:

[...] She had been so tame, so confiding, letting me, at any rate spiritually speaking, hold her tiny, quivering body in one hand and stroke her furry head—and now, I’d thrown her away. Oh, I could have kicked myself.

She stood up. "I have no plans. But—it’s very late. You must go now, please."

How could I get her back? I wanted her back. I swear I was not acting then.

"Do feel that I am your friend," I cried. "You will let me come tomorrow, early? You will let me look after you a little—-take care of you a little? You'll use me just as you think fit?” (Mansfield, 2012, p. 133)

We are not convinced by Raoul's display of chivalry because of a hint of self-dramatisation in the voice when he swears that he is "not acting". A few sentences later we have learned that he also abandons Mouse by failing to return to the hotel as he promises: "Je ne parle pas français. That was her swan song for me" (Mansfield, 2012, p. 133). "Unlike most of Mansfield’s complex, many-sided female characters”, as Sydney Janet Kaplan puts it, "Mouse is simply woman as victim” (Kaplan, 1991, p. 44). There is no doubt that Mouse is a victim of broken promises, but the clichéd and rather theatrical manner in which Raoul describes Mouse throughout the story puts Kaplan's claim that the character of Mouse is “one-dimensional” (Kaplan, 1991, p. 44) into doubt. A rereading of the key passage devoted to Mouse, I suggest, sheds more light on this "complex, many-sided” yet insufficiently analysed character:

[...] They showed her, sitting up very straight, her lovely little face more like a drawing than a real face-every line so full of meaning and so sharp cut against the swimming dark.

\footnotetext{
${ }^{5}$ Giacomo Puccini, Madame Butterfly (1904), an opera based on the love of a Japanese geisha, Ciocio-san (nicknamed Butterfly), for Pinkerton, an American naval officer. For a more detailed introduction to the opera, see Osborne (1981), pp. 145-171.

${ }^{6}$ See Ferenzci, (1952), pp. 296-318.
} 
For Mouse was beautiful. She was exquisite, but so fragile and fine that each time I looked at her it was as if for the first time. She came upon you with the same kind of shock that you feel when you have been drinking tea out of a thin innocent cup and suddenly, at the bottom, you see a tiny creature, half butterfly, half woman, bowing to you with her hands in her sleeves.

As far as I could make out she had dark hair and blue or black eyes. Her long lashes and the two little feathers traced above were most important.

She wore a long dark cloak such as one sees in old-fashioned pictures of Englishwomen abroad. Where her arms came out of it there was fur-fur round her neck, too, and her close-fitting cap was furry.

"Carrying out the mouse idea," I decided.

Ah, but how intriguing it was-how intriguing! Their excitement came nearer and nearer to me, while I ran out to meet it, bathed in it, flung myself far out of my depth, until at last I was as hard put to it to keep control as they. (Mansfield, 2012, p. 126)

The word "intriguing" has been stressed by the narrator twice as Mouse, in this passage, emerges in a variety of complex and subtle ways. Obviously, Raoul is curious about the secret liaison between Mouse and Dick and fascinated by Mouse's beauty. The resemblance between Raoul's self-description and that of Mouse, however, suggests another reading. She, too, has “dark hair” and black eyes with "long lashes”. He sees Mouse as "a tiny creature, half butterfly, half woman, bowing with her hands in her kimono sleeves”; a few paragraphs earlier, he portrays himself as Madame Butterfly. Seen in this light, Raoul sees Mouse not so much as a love interest as, in the phrase of C. A. Hankin, "the woman who he might have been" (Hankin, 1983, p. 160), ${ }^{7}$ or a love rival who vies with him for Dick's attention. On the other hand, he has already found out that there is actually something "boyish" about the unnamed woman: when they are first introduced, he notices that "she held out her hand in that strange boyish way Englishwomen do, and standing very straight in front of" him "with her chin raised” (Mansfield, 2012, p. 125). His observation invites us to ponder if wearing fur is a way for Mouse to mask her boyishness in order to deceive the male characters in the story.

To answer this question, I shall begin by teasing out the association between womanliness and mousiness, which can be traced back to the Elizabethan era, when mouse was a common term of endearment, especially between husband and wife. In a letter dated 2nd May 1593, Edward Alleyn addresses his wife Joan as "My good sweetheart and loving mouse" (Kemp, 2009, p. 160). Other examples can be found in the plays of one of Mansfield's favourite writers, Shakespeare: In Act I, Scene 5 of Twelfth Night, Clown calls Olivia "my mouse of virtue” (Shakespeare, 2011, p. 1196); in Act IV, Scene 4 of Romeo and Juliet, Lady Capulet tells her husband that he has "been a mouse-hunt" [pursuer of women] in his time (Shakespeare, 2011, p. 1033). In light of these observations, we can see that the very idea of nicknaming a woman "mouse" is a way of conferring a mask of womanliness onto her. In other words, the name "mouse" is a mask of womanliness. Similarly, throughout "Je ne parle pas français”, Dick calls the unnamed woman Mouse. For instance, he speaks tenderly to her: "You must be tired, Mouse. Sit down" (Mansfield, 2012, p. 128). Receiving the nickname given by Dick, Mouse is masked as an object of his affection by his speech. In her book, Glamour: Women, History, Feminism, Carol Dyhouse underscores the link between fur and femininity:

In the 1920s, advertisements in Vogue for the upmarket French fur house Révillon Frères promised that women would literally weep with gratitude to men who indulged them with furs ("A Révillon fur is a gift to win tears of thanksgiving from the most pampered of her sex.”). (Dyhouse, 2010, p. 27)

\footnotetext{
${ }^{7}$ C. A. Hankin claims that there is a sense in which Mouse is the woman Raoul might have been; "and thus she represents his alternate self, or double”. See Hankin (1983), p. 160.
} 
As Dyhouse's example indicates, wearing fur not only increases a woman's charm but also reassures her that she is a woman who is "pampered" by her lover. The function of clothes in Mansfield's stories, as Angela Smith claims, is "to manipulate others, or to create a protective façade": "Laura's mother controls Laura's rebellion in 'Garden Party' by dropping an elegant black hat on her daughter's head, and Miss Brill's fur is a source of comfort, and then humiliation” (Smith, 1999, p. 48). Here "a protective façade" indicates that clothes can function as a form of defense and disguise. In "Je ne parle pas français”, fur is what Rivière calls "a mask of womanliness" that Mouse wears "to avert anxiety and the retribution feared from men” (Rivière, 1986, p. 35). Mouse wears a fur muff to mask her boyish hands, effectively using what Freud calls "fur as a fetish"8 to manipulate men. At the train station, Mouse hails Dick "with her minute muff” (Mansfield, 2012, p. 125). At the hotel, Mouse successfully pushes the garcon to serve her tea quickly by masquerading as a helpless woman who needs to be saved by a cup of tea: "And suddenly she raised her muff as though her hands were clasped inside it, and she was telling the pale, sweaty garçon by that action that she was at the end of her resources, that she cried out to him to save her with 'Tea. Immediately!'” (Mansfield, 2012, p. 128). After a while, Dick asks Mouse: “Won’t you take off your coat, Mouse?” But she insists on wearing her fur-trimmed coat indoors: “No thanks. Not just now” (Mansfield, 2012, p. 128). Responding to the nickname given by her lover, Mouse hopes to keep up the masquerade of being his beloved by wrapping herself in fur.

\section{The Becoming-Mouse}

Being called her lover’s Mouse, however, also means being patronized and literally belittled, as shown in the letter Dick leaves to Mouse:

Mouse, my little Mouse,

[...] All I've got to do is-just to tell you this and go. I couldn't have gone off without telling you. You'd have been frightened. And you must not be frightened. You won’t—will you? I can’t bear-but no more of that. And don't write. I should not have the courage to answer your letters and the sight of your spidery handwriting — [...] (Mansfield, 2012, pp. 131-132)

As the letter indicates, Dick calls the woman "my little Mouse" in order to alleviate his guilt over deserting her: Mouse is unimportant since she is little, and she is at his mercy because she belongs to him. At the same time, Dick’s fear of what may hide behind her “drawing”-like, “lovely little face” (Mansfield, 2012, p. 126), is further intimated by the arachno-phobic mention of her "spidery handwriting” (Mansfield, 2012, p. 132).

Murry, the first reader of the story, told Mansfield that he was "so passionately fond of the Mouse" that he got upset by what happened to her and Dick. In a letter dated 23 February1918, he writes:

My disappointment as a child was my satisfaction as an artist [...] "Sun \& Moon” were really tinies. His tragedy would be put right. But Mouse \& Dick, they were too much like us. If they had been exactly like it wouldn’t have upset me because I know we're alright. But they were different, our brothers \& sisters spiritually. (Murry, 1983, p. 27)

As the letter reveals, Mouse and Dick are at least, in part, masks for Mansfield and Murry respectively. As Kaplan argues, Dick is partially modelled on Murry, as suggested by an unfinished sentence in her letter (dated 3 and 4 February 1918) to Murry about the story’s origin: “The African laundress I had a bone of—but only a

\footnotetext{
${ }^{8}$ Sigmund Freud suggests that "the part played by fur as a fetish owes its origin to an association of the hair of the mons Veneris". See Freud (1962), p. 21; "Most of those animals which are utilised as genital symbols in mythology and folklore play this part also in dreams: the fish, the snail, the cat, the mouse (on account of the hairiness of the genitals)", says Freud in The Interpretation of Dreams, p. 236.
} 
bone-Dick Harmon of course is partly is [sic]" (Mansfield, 1987, p. 56). Two months after she finished "Je ne parle pas français", 9 she refers to herself as "your tiny timid loving Mouse" in a letter to Murry (9 April 1918) (Mansfield, 1987, p. 159). Two later letters to Murry dated 21 and 23 October 1920 are both autographed "Souris [Mouse]" (Mansfield, 1996, p. 81). These examples embody Mansfield's Wildean belief ${ }^{10}$ that "there is no separating Art \& Life”, as she writes in a letter to Murry's younger brother Richard (10 December 1920) (Mansfield, 1996, p. 148). In addition to mice in "Je ne parle pas français" and "The Daughters of the Late Colonel” $(1920)^{11}$, numerous other tiny creatures appear in her short stories. ${ }^{12}$

Mansfield also has a mask in D. H. Lawrence's Women in Love (1920). If we accept that Gudrun Brangwen is a mask for Mansfield, Lawrence recognises her fascination with diminutive animality in a question posed by Ursula Brangwen to Hermione:

Isn't it queer that she [Gudrun] always likes little things? She must always work small things, that one can put between one's hands, birds and tiny animals. She likes to look through the wrong end of the opera glasses, and see the world that way—why is it, do you think? (Lawrence, 1978, p. 88)

Why does Mansfield like to write about small animals? In "Katherine Mansfield’s Menagerie”, Melinda Harvey links Mansfield's interest in two-winged animals with her illness: first, "mosquitoes, flies and the like were associated, especially in the late-nineteenth and early-twentieth-century, with the spread of disease like tuberculosis” (Harvey, 2001, p. 208); Toby Silverman Zinman suggests that birds in Mansfield's stories represent "the victim: small, frail and equipped with the means of escape, yet ultimately and inevitably defeated” (Zinman, 1978, p. 461). Certainly, as Vincent O’Sullivan suggests, Mansfield did use the dying fly and the entrapped canary as analogies for herself, as seen in the letters, notebook entries and the stories she composed in her last year (O’Sullivan, 2011). Unlike Harvey, Zinman and O’Sullivan—who all emphasise the frailty embodied in the smallness of insects and birds-I want to highlight the advantage of becoming a small mouse in Mansfield's "Je ne parle pas français" by drawing a comparison with the writings of her contemporary, Franz Kafka.

Mansfield makes multiple statements about the importance of "the defeat of the personal"13 in the act of writing in order to enter into and take possession of her subjects, including non-human animals. In a letter to the painter Dorothy Brett dated 11 October 1917, she relates her “thrilling” experience of writing about animals:

When I write about ducks I swear that I am a white duck with a round eye, floating in a pond fringed with yellow blobs and taking an occasional dart at the other duck with the round eye, which floats upside down beneath me. In fact this whole process of becoming the duck [...] is so thrilling that I can hardly breathe, only to think about it. (Mansfield, 1984, p. 330)

The phrase "becoming the duck" evokes what Deleuze and Guattari call "the becoming-animal", in their book, Kafka: Toward a Minor Literature: "To become animal is to participate in movement, to stake out a path of escape in all its possibility” (Deleuze \& Guattari, 1986, p. 13):

\footnotetext{
9 Mansfield began writing “Je ne parle pas français” on 29 January, 1918. See Kaplan (2011), p. 45.

${ }^{10}$ For Wilde's influence on Mansfield, see Kaplan (1991), pp. 19-35.

11 “Silence again. There came a little rustle, a scurry, a hop. 'A mouse,' said Constantia.” Quoted from “The Daughters of the Late Colonel” (Mansfield, 2012, p. 267).

12 In addition to "The Fly" (1922) and “The Canary” (1922), we can find other small animals such as ducks in "Prelude” (1917), sparrows in "A Suburban Fairytale” (1919), and doves in "Mr. and Mrs. Dove” (1921).

13 “At the back of my mind I am so wretched," Mansfield notes in one journal entry, "but all the while I am thinking over my philosophy—the defeat of the personal” (Mansfield, 1997, p. 190).
} 
The metamorphosis is a sort of conjunction of two deterritorializations, that which the human imposes on the animal by forcing it to flee or to serve the human, but also that which the animal proposes to the human by indicating ways-out or means of escape that the human would never have thought of by himself. (Deleuze \& Guattari, 1986, p. 35)

The evidence regarding Mansfield's familiarity with the German-language writer's work has yet to be discovered, but their shared interest in writing about small animals cannot be neglected. As J. Lawrence Mitchell observes, the miniature in Mansfield's stories—such as a doll's house, "a tiny-creature, half butterfly, half woman", a caged canary—is privileged, while the "movement towards the gigantic"—a growing bird, a swelling aloe, a poppy that comes alive—is "implicitly threatening” (Mitchell, 2004, p. 34). ${ }^{14}$ Like Mansfield, Kafka is, as Deleuze and Guattari put it, "fascinated by everything that is small. If he doesn't like children that is because they are caught in an irreversible becoming-big; the animal kingdom, in contrast, involves smallness and imperceptibility" (Deleuze \& Guattari, 1986, p. 37). In a similar vein, "the gigantic" in Kafka's stories, such as the "gigantic insect" in "The Metamorphosis" (Kafka, 2005, pp. 89-139) or the "giant mole" in "The Village Schoolmaster [The Giant Mole]” (Kafka, 2005, pp. 168-182), is disturbing.

In light of the resemblance between the two writers, Mansfield's fascination with mice could be interpreted in relation to Elias Canetti's comments on Kafka's penchant for self-diminishment. In his Kafka's Other Trial: The Letters to Felice, Canetti remarks that Kafka would typically respond to a show of force by withdrawing power from himself or by transforming into something small:

Since he [Kafka] abominated violence, but did not credit himself with the strength to combat it, he enlarged the distance between the stronger entity and himself by becoming smaller and smaller in relation to it. Through this shrinkage he gained two advantages: he evaded the threat by becoming too diminutive for it, and he freed himself from all exceptionable means of violence; the small animals into which he liked to transform himself were harmless ones. (Canetti, 1974, pp. 89-90) $)^{15}$

In Kafka's “Josephine the Singer, or the Mouse folk” (1924), the mouse singer's piping, we are told, "comes almost like a message from the whole people to each individual; Josephine's thin piping amidst grave decisions is almost like our people’s precarious existence amidst the tumult of a hostile world” (Kafka, 2005, p. 367). As Mansfield wrote to Murry from Bandol, the south of France, on 3 February 1918, it was "an extremely deep sense of hopelessness", "a cry against corruption", "Not a protest", which inspired "Je ne parle pas français” (Mansfield, 1987, p. 54). It is hard to imagine a creature more ideally suited to voice "a cry against corruption", "Not a protest", than a squeaking mouse. Unlike the mouse singer in Kafka's "Josephine the Singer, or the Mouse folk", who "stamps her feet" and bites "in most unmaidenly fashion" whenever her requests are refused (Kafka, 2005, p. 364), Mouse in Mansfield’s “Je ne parle pas français” smiles at her grief; as the narrator describes it, "she took the handkerchief down and gave me a final glimmer". Knowing all along that Dick was going to desert her, Mouse appears to be defensively silent in his presence:

“[...] We’ve taken years to come. Haven’t we?” To her. But she [Mouse] did not answer. She bent her head and began stroking her grey muff; she walked beside us stroking her grey muff all the way.

[...]

"You must come!” said Dick to the little fox-terrier [Raoul]. And again he [Dick] made that big awkward turn towards her.

"Get in, Mouse."

\footnotetext{
14 In his article, “Katherine Mansfield and the Aesthetic Object” (2004), Mitchell uses Susan Stewart’s terms, "the miniature” and "the gigantic". See Stewart (1993).

15 Quoted in Danta (2008), p. 162.
} 
And Mouse got in the black hole and sat stroking Mouse II and not saying a word. (Mansfield, 2012, pp. 125-126)

As the last line of this quotation intimates, Mouse is becoming a mouse, as suggested by "the black hole" (which is a substitute for the black taxi Raoul calls for them), and "Mouse II" (her grey muff made of animal fur, presumably). Mouse's transformation into a mouse by wearing fur recalls the picture of a lady "with a fur cap on and a fur stole, sitting upright and holding out to the spectator a huge fur muff into which the whole of her forearm had vanished” (Kafka, 2005, p. 89) described at the opening of Kafka’s “The Metamorphosis”. The lady's vanishing into an animal covering seems to function as an inspiration for Gregor's metamorphosis into vermin form. In the same vein, Mouse II shows Mouse, in Deleuze and Guattari’s phrase, “ways-out or means of escape that the human would never have thought of by himself”. Becoming is, as Deleuze puts it in his The Logic of Sense, a simultaneity

...whose characteristic is to elude the present. Insofar as it eludes the present, becoming does not tolerate the separation or the distinction of before and after, or of past and future. It pertains to the essence of becoming to move and to pull in both directions at once. (Deleuze, 1990, p. 1) ${ }^{16}$

Mouse is unable to make her way out of an unofficial and insecure relationship with Dick, however, she finds a means of "eluding the present" by becoming a mouse and stroking Mouse II, as if communicating with a fellow mouse in "the ultrasonic range," "beyond human hearings" (Vanderlip, 2001, p. 30). ${ }^{17}$ Likewise, in "A Suburban Fairy Tale" (1919), Little B saw the sparrows on the grass outside the window of their house changing into tiny little boys. He tells his parents Mr. and Mrs. B that the sparrows are little boys but "nobody noticed his nonsense". When his parents finally went over to the window and saw Little B playing with other little boys with wing-like thin arms, they opened the window and asked Little B to come into the house. "But it was too late. The little boys were changed into sparrows again, and away they flew—out of sight—out of call” (Mansfield, 2012, pp. 172-173). Becoming a little sparrow is for Little B a means of escaping "the present", a life which is "too big and too violent” (Mansfield, 2012, p. 170).

If Mouse, the Englishwoman, is a heroine who resembles Mansfield, "a New Zealander who often felt alienated by life in London" (Smith, 2011, p. 194) and a "born actress and mimic" who "took colour from the company she was in" (Smith, 2000, pp. 47-48), ${ }^{18}$ as Ida Baker observes, she must know how to survive in Paris thanks to the art of changing masks. In addition to saying, paradoxically, in French, that she does not speak French ("Je ne parle pas français"), "not saying a word" is a speechless speech, one of the masks used by Mouse to express "an extremely deep sense of hopelessness".

Mansfield could not change the fact that she had to travel constantly between England and Europe in search for the cure for her tuberculosis, but she was able to use clothes as “a protective façade” (in Smith's term) (Smith, 2000, p. 48). In a letter dated 1 Jan. 1931, Woolf tells Vita Sackville-West that the novelist Stella Benson's dressing style reminds her of that of Mansfield: "Anderson [Stella Benson] seems to me extremely good-puts a line round herself completely, as Katherine Mansfield used to wish to do, when she bought a tailor made coat” (Woolf, 1979, p. 271). Correspondingly, living in a time and space of estrangement, Mouse is

\footnotetext{
${ }^{16}$ Quoted in Bruns (2007), p. 704.

17 "Mice make a variety of sounds, although to humans they simply sound like high-pitched squeaks". Mice communicate in "the ultrasonic range”, "beyond human hearing”. See Vanderlip (2001), p. 30.

${ }^{18}$ Ida Baker, one of Mansfield's intimates, as Angela Smith suggests, "is observant about a kind of chameleon quality in Mansfield's clothes and appearance in her memoir: 'She was a born actress and mimic, and even in her ordinary everyday life took colour from the company she was in”” (Smith, 2000, pp. 47-48).
} 
powerless to improve the external conditions governing her life. But she can influence her immediate environment above all by means of her masks - namely, womanliness and animality: Mouse finds her way back into her burrow in a foreign city by wearing a mouse-disguise, which consists of a fur muff, a cloak with fur trim and a fur cap. She lives inside her fur like living inside her burrow, "where she could hide and keep herself to herself and stay as long as she liked, not disturbing anybody, and nobody worrying her” (Mansfield, 2012, p. 297). ${ }^{19}$

\section{Conclusion}

To conclude, in this paper I have demonstrated how Mansfield's art of changing masks has confounded what Woolf calls the "sentimentality" of her stories by looking at how speech and facial expressions, gender, and animality are adopted as masks for Mouse to meet every moment in "Je ne parle pas français". In other words, through tracing these kinds of masking through, the essay argues that the seemingly unmasked expressions such as tears or sentiments conveyed by characters only serve as "another mask prepared beneath" the overlying mask rather than the true self revealed. That there is only a mask beneath the mask has not only shifted our conception of masking as covering the true self but also challenged the conventional notion of a selfhood "which is continuous and permanent", as Mansfield writes in a journal entry of 29 April 1920: "True to oneself? Which self? Which of my many-well, really, thats [sic] what it looks like coming to-hundreds of selves” (Mansfield, 1997, p. 204).

\section{References}

Alpers, A. (1987). The life of Katherine Mansfield. Oxford: Oxford University Press.

Bennett, A. (2004). Katherine Mansfield. Tavistock: Northcote House.

Bruns, G. L. (2007 Autumn). Becoming-animal (some simple ways). New Literary History, 38(4), 703-720.

Canetti, E. (1974). Kafka's other trial: The letters to Felice. London: Calder and Boyars.

Danta, C. (2008). Kafka's mousetrap: The fable of the dying voice. SubStance, 37(3), 152-168.

Deleuze, G. (1990). The logic of sense. New York: Columbia University.

Deleuze, G., \& Guattari, F. (1986). Kafka: Toward a minor literature. Minneapolis: University of Minnesota Press.

Dunbar, P. (1997). Radical Mansfield: Double discourse in Katherine Mansfield's short stories. Basingstoke: Palgrave Macmillian.

Dyhouse, C. (2010). Glamour: Women, history, feminism. London: Zed Books.

Eliot, T. S. (1934). After strange gods: A primer of modern heresy. London: Faber and Faber.

Eliot, T. S. (1997). Tradition and the individual talent. In The sacred wood: Essays on poetry and criticism (pp. 39-49). London: Faber and Faber.

Ferenzci, S. (1952). The nosology of male homosexuality (homo-eroticism). In E. Jones (Trans.), First contributions to psycho-analysis (pp. 296-318). London: Hogarth.

Freud S. (1997). The interpretation of dreams. Ware: Wordsworth Editions.

Freud, S. (1962). Three essays on the theory of sexuality. London: Hogarth.

Goldman, M. (1975). The actor's freedom: Toward a theory of drama. New York: Viking Press.

Hankins, L. K. (1993 Winter). A splice of reel life in Virginia Woolf's “Time Passes”: Censorship, cinema and "the usual battlefield of emotions”. Criticism, 35(1), 91-114.

Hanson, C. (1990). Katherine Mansfield (1888-1923). In B. K. Scott (Ed.), The gender of modernism (pp. 298-305). Bloomington: Indiana University Press.

Harvey, M. (2001). Katherine Mansfield's menagerie. In J. Wilson, S. Reid and G. Kimber (Eds.), Katherine Mansfield and

${ }^{19}$ Mansfield, “Life of Ma Parker”: “Oh, wasn’t there anywhere where she [Ma Parker] could hide and keep herself to herself and stay as long as she liked, not disturbing anybody, and nobody worrying her? Wasn't there anywhere in the world where she could have her cry out—at last?” (Mansfield, 2012, p. 297). 
literary modernism (pp. 202-210). London: Continuum.

Heath, S. (1986). Joan Rivière and the masquerade. In V. Burgin, J. Donald and C. Kaplan (Eds.), Formations of fantasy (pp. 45-61). London: Methuen.

Kafka, F. (2005). The complete short stories. London: Vintage.

Kaplan, S. J. (1991). Katherine Mansfield and the origins of modernist fiction. Ithaca and London: Cornell University Press.

Kaplan, S. J. (2011). “A furious bliss”: Katherine Mansfield and John Middleton Murry 1916-1918. In G. Kimber and J. Wilson (Eds.), Celebrating Katherine Mansfield: A centenary volume of essays. Basingstoke: Palgrave Macmillian.

Kemp, T. D. (2009). Women in the age of Shakespeare. Santa Barbara: Greenwood.

Kimber, G., \& O’Sullivan, V. (Eds.). (2012). The Edinburgh edition of the collected works of Katherine Mansfield (Vol. 2). Edinburgh: Edinburgh University Press.

Lawrence, D. H. (1978). Women in love. London: Penguin.

Mansfield, K. (1977). The letters and journals of Katherine Mansfield: A selection. Harmondsworth: Penguin.

Mansfield, K. (1984). The collected letters of Katherine Mansfield. Oxford: Clarendon Press.

Mansfield, K. (1987). The collected letters of Katherine Mansfield. Oxford: Clarendon Press.

Mansfield, K. (1993). The collected letters of Katherine Mansfield. Oxford: Clarendon Press.

Mansfield, K. (1996). The collected letters of Katherine Mansfield. Oxford: Clarendon Press.

Mansfield, K. (1997). The Katherine Mansfield notebooks. Minneapolis: University of Minnesota Press.

Mansfield, K. (2012). The Edinburgh edition of the collected works of Katherine Mansfield. Edinburgh: Edinburgh University Press.

Mitchell, J. L. (2004). Katherine Mansfield and the aesthetic object. Journal of New Zealand Literature, 22, 31-54.

Murry, J. M. (1983). The letters of John Middleton Murry to Katherine Mansfield. London: Constable.

O’Sullivan, V. (2011). Signing off: Katherine Mansfield’s last year. In G. Kimber and J. Wilson (Eds.), Celebrating Katherine Mansfield: A centenary volume of essays (pp. 13-27). Basingstoke: Palgrave Macmillian.

Osborne, C. (1981). The complete operas of Puccini: A critical guide. London: Victor Gollancz.

Rivière, J. (1986). Womanliness as masquerade. In V. Burgin, J. Donald, and C. Kaplan (Eds.), Formations of fantasy (pp. 35-44). London: Methuen.

Shakespeare, W. (2011). The Arden Shakespeare complete works. (Revised edition). London: Methuen Drama.

Smith, A. (1999). Katherine Mansfield and Virginia Woolf: A public of two. Oxford: Clarendon Press.

Smith, A. (2000). Katherine Mansfield: A literary life. Basingstoke: Palgrave.

Smith, A. (2011). Mansfield and Dickens: "I am not reading Dickens idly”. In G. Kimber and J. Wilson (Eds.), Celebrating Katherine Mansfield: A centenary volume of essays (pp. 189-201). Basingstoke: Palgrave Macmillan.

Stead, C. K. (1977). Introduction. In The letters and journals of Katherine Mansfield: A selection (pp. 9-20). Harmondsworth: Penguin.

Stewart, S. (1993). On longing: Narratives of the miniature, the gigantic, the souvenir, the collection. Durham and London: Duke University Press.

The Oxford English dictionary. (1989). Oxford: Oxford University Press.

Vanderlip, S. (2001). Mice: A complete pet owner's manual. New York: Barron’s.

Vickers, S. (2012). My debt to Katherine Mansfield. In The Katherine Mansfield society annual birthday lecture, no. 3 (pp. 7-15). Bath: Katherine Mansfield Society Publications.

Woolf, V. (1978). The diary of Virginia Woolf. London: Hogarth.

Woolf, V. (1979). The letters of Virginia Woolf. London: Hogarth.

Zinman, T. S. (1978 Autumn). The snail under the leaf: Katherine Mansfield’s imagery. Modern Fiction Studies, 24(3), 457-464. 